\title{
Modelling Satisfaction and Behavioural Intention of Malaysian Fine Dining Restaurants
}

Salim Abdul Talib, Rahmat Hashim, Rosmaliza Muhammad

To Link this Article: http://dx.doi.org/10.6007/IJARBSS/v11-i13/8553

DOI:10.6007/IJARBSS/v11-i13/8553

Received: 11 November 2020, Revised: 10 December 2020, Accepted: 24 November 2020

Published Online: 25 January 2021

In-Text Citation: (Abdul Talib et al., 2021)

To Cite this Article: Abdul Talib, S., Hashim, R., \& Muhammad, R. (2021). Modelling Satisfaction and Behavioural Intention of Malaysian Fine Dining Restaurants. International Journal of Academic Research in Business and Social Sciences, 11(13), 344-361.

\section{Copyright: (c) 2021 The Author(s)}

\section{Published by Human Resource Management Academic Research Society (www.hrmars.com)}

This article is published under the Creative Commons Attribution (CC BY 4.0) license. Anyone may reproduce, distribute, translate and create derivative works of this article (for both commercial and non-commercial purposes), subject to full attribution to the original publication and authors. The full terms of this license may be seen

at: http://creativecommons.org/licences/by/4.0/legalcode

Special Issue: Beyond 2021 and COVID-19 - New Perspective in the Hospitality \& Tourism Industry, 2021, Pg. 344 - 361

Full Terms \& Conditions of access and use can be found at http://hrmars.com/index.php/pages/detail/publication-ethics 


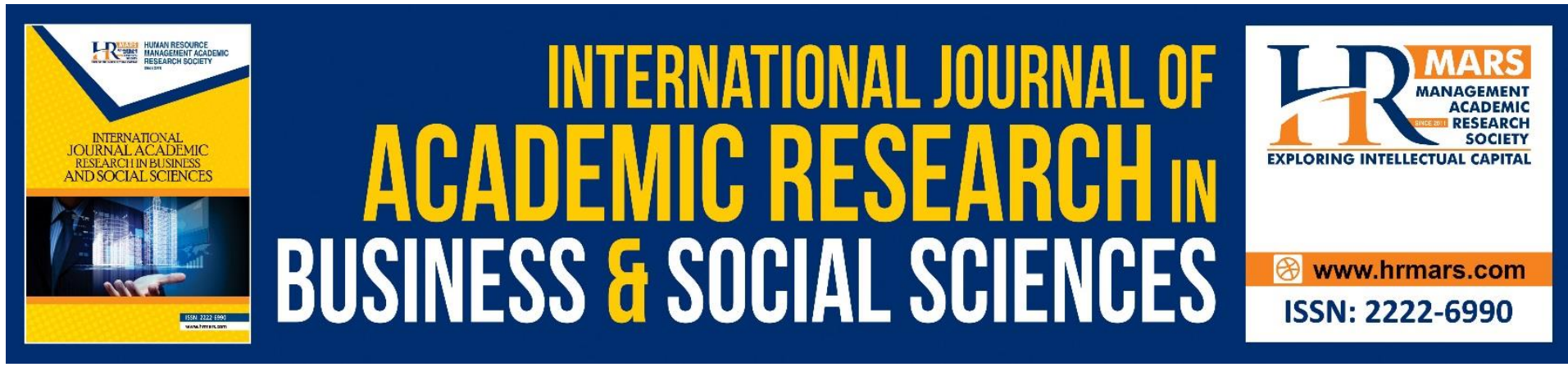

\title{
Modelling Satisfaction and Behavioural Intention of Malaysian Fine Dining Restaurants
}

\author{
Salim Abdul Talib ${ }^{1}$, Rahmat Hashim², Rosmaliza Muhammad ${ }^{1}$ \\ ${ }^{1}$ Faculty of Hotel and Tourism Management, Universiti Teknologi MARA, Puncak Alam \\ Campus, 42300, Selangor, Malaysia, ${ }^{2}$ Taylor's University Lakeside Campus, 47500 Subang \\ Jaya, Selangor Malaysia
}

\begin{abstract}
Consumer satisfaction was long recognized by scholars and practitioners as one major ingredient for business survival and prosperity. Hence, the main purpose of this study was to offer an integrated approach to understanding consumer satisfaction and post-dining behavioural intentions by examining the causal relationship among five constructs of fine dining restaurant with satisfaction and behavioural intentions. The Likert scale survey instrument was used to collect data via the 'drop-off and collect' survey technique. The sample was drawn from participating restaurants in the Malaysia International Gastronomy Festival 2017. Four hundred and nineteen useable questionnaires were garnered from eight fine dining restaurants that agreed to participate in the study. A research model based on the expectancy-disconfirmation paradigm investigating the relevant relationships among the constructs by using a structural equation modelling (SEM) approach was proposed and tested. This study examined a mediating model of the relationship between the restaurant service/product dimensions, marketing dimension centred on customer-based brand equity constructs, satisfaction and revisit intention. A parsimonious model of restaurant satisfaction and behavioural (revisit) intention was successfully developed and the proposed framework was substantially validated with four hypotheses supported and seven not. Theoretical and practical implications with relevant and importance to academicians and practitioners were offered.
\end{abstract}

Keywords: Consumers' Satisfaction, Behavioural Intention, Malaysian Fine Dining Restaurant, Expectancy-Disconfirmation Model, Malaysia International Gastronomy Festival and Structural Equation Modelling.

\section{Introduction}

The Malaysian foodservice industry, including the fine dining segment has a great economic potential. Since the food and beverage industry is paramount to our country's economy, promotional efforts to popularize these establishments are done by relevant authorities. This is in line with the Malaysia Tourism Transformation Plan goals of welcoming a total of 36 million tourists to Malaysia and registering RM168 billion in tourist receipts by the year 2020 (Tourism Malaysia, 2018). The fine dining restaurant segment has gained 
popularity among Malaysians, especially in the urban areas like Kuala Lumpur. The high concentration of well to do upper-echelons of the society, expatriates and tourists, as well as corporate offices in these urban areas provides great demand for upscale restaurants. These kinds of restaurants are frequented for both business and leisure purposes. One such effort is The Malaysian International Gourmet Festival (MIGF), the country's premier fine dining event featuring Malaysia's very best fine dining restaurants.

The aims of this Gourmet Festival are to increase the size of the local fine dining restaurants, inculcate interest in the local fine dining context, and promoting Malaysia as an international food or gastronomy tourism destination of choice. This festival has also been recognized by Tourism Malaysia as one of the country's top 50 official events for Visit Malaysia campaigns (http://migf.com/welcome.html). The food service industry, particularly the fine dining sector, is strongly influenced by developments in tourism as well as other cyclical and contextual factors such as demography, lifestyle, national or regional customs and circumstantial/worldly events that can change things from optimism to uncertainty (Fryet, 2015). Disasters may occur at a sudden and will affect the world economy at any given time. Events like the economic crisis that struck the Asia-pacific region in 1997-1998, the Asian currency crisis and economic depression, bomb attacks by the so-called terrorist in various parts of the world and the SARS epidemic scare of 2003 had halted tourism activities and limits the spending power of consumers. This has and can impact the foodservice sector, especially the upscale fine dining restaurants (Sung, Wan, Young \& Youngjo, 2017; ScottDelany \& Finn, 2017).

The Malaysian foodservice industry, including the fine dining segment is thriving and has a great economic potential. This is partly due to the concerted effort of the government and non-governmental organization in promoting Malaysia as a gastronomic tourism destination, including "hedonic" lifestyle trends of the society. Surprisingly, there are scant efforts on the part of practitioners and academia to conduct research, empirical or otherwise, to understand the business better, especially on issues relating to consumers' satisfaction and behavioural intentions in the Malaysian fine dining restaurant segment. The study of consumer satisfaction in the restaurant industry has traditionally focused on individual satisfaction on the performance of the products and services of the restaurant dimensions only ( $\mathrm{Hu}, 2005)$. Other dimensions have not received much attention despite the uniqueness of the restaurant industry where it runs two critical components of business operations i.e. manufacturing (kitchen operations) and customer relationship management (Biswas \& Cassel, 1996, Santouridis \& Veraki, 2017).

There are also very little studies on the marketing dimension of the restaurant in the literature which resulted in a lack of understanding about fine dining restaurant product/service and marketing dimension linkages with consumer satisfaction and behavioural intentions when factors relating to customer satisfaction and behavioural intentions are fundamental when formulating an organization's business and marketing strategies. To address these gaps, a theoretical model was developed and proposed. The goals of this research is to offer an integrated approach to understanding consumer satisfaction and behavioural intentions by examining the theoretical and empirical evidence on the causal relationships among five constructs representing the service/product and 
marketing dimensions of fine dining restaurant. The specific objectives of this study are as follows:

i.To investigate the association of the restaurant service/product dimensions and customer's satisfaction;

ii.To determine restaurant marketing dimensions and satisfaction

iii.To determine the mediating factor of satisfaction in the relationship between service and marketing dimensions and revisit intention.

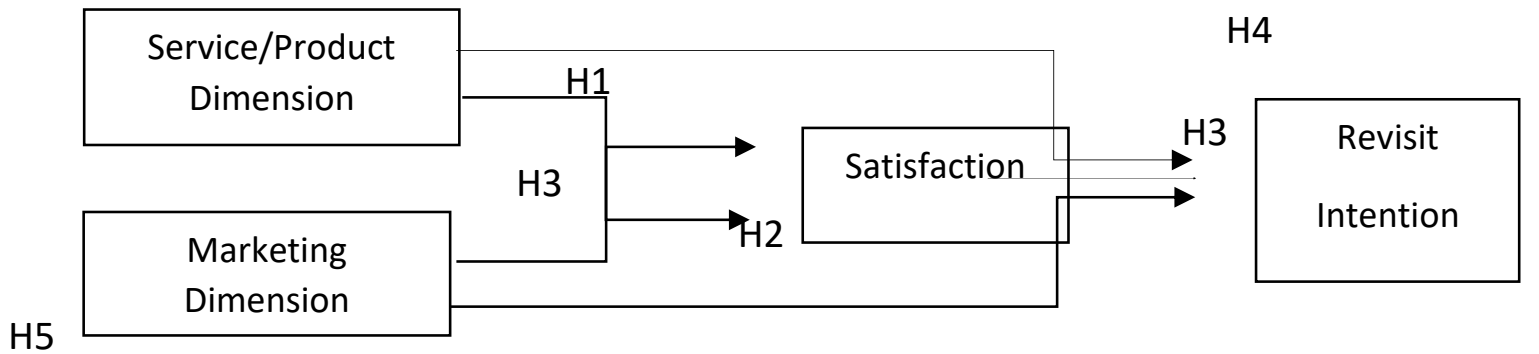

Figure 1.0: The Study's Theoretical Framework

This study's theoretical framework was guided by the expectancy-disconfirmation theory/model first advocated by Lewin (1938) and later updated by Oliver (1980) and is believed to have received the widest acceptance in modeling consumer satisfaction because of its broadly applicable conceptualization (Yuksel \& Yuksel, 2008, Grimmelikhuijsen \& Porumbescu, 2017). Expectancy-disconfirmation theory asserts that individuals make purchase decisions based on their expectations of the outcomes of a specific action. Positive disconfirmation occurs if the product or service is better than expected, whereas a performance worse than expected results in a negative disconfirmation. A match between the two leads to confirmation, that is, neither satisfaction nor dissatisfaction. It has been exemplified that positive disconfirmation will be transpired into satisfaction and negative disconfirmation translate into dissatisfaction (Grimmelikhuijsen \& Porumbescu, 2017).

By using this theory via a direct method of assessment, consumer's satisfaction level with the attributes or chosen constructs of the restaurant will be able to be determined. Through the direct assessment method, instead of asking participants two full sets of questions to assess their perceptions and expectations, only one set is used. This method uses a summaryjudgment scale to answer the question. The scale contains options ranging from "worse than expected" to "better than expected" to measure expectancy disconfirmation and eliminates the need to calculate different scores (Yuksel and Rimmington, 1998). This method has been used by many researchers (such as Kivela, Inbakaran \& Reece, 1999; Grimmelikhuijsen \& Porumbescu, 2017) to assess consumer satisfaction in hospitality (foodservice/restaurant) settings. Five (5) hypotheses were derived from the theoretical framework.

$\mathrm{H}_{1}$ : The higher the restaurant service/product dimension (service quality, product quality and atmospherics quality), the higher the satisfaction level.

$\mathrm{H}_{2}$ : The higher the marketing dimension (brand image and customer relationship management), 
the higher the satisfaction level.

$\mathrm{H}_{3}$ : The higher the restaurant service/product dimension (service quality, product quality and

atmospherics quality), the higher the revisit intention.

$\mathrm{H}_{4}$ : The higher the restaurant marketing dimensions (brand image and customer relationship

management), the higher the revisit intention.

$\mathrm{H}_{5}$ : $\quad$ The higher the satisfaction level, the higher the revisit intention.

\section{Literature Review}

The socio-economic and political factors of a country are not the only reasons that "make or break" a restaurant. Understanding consumers behavioural pattern in making purchase decisions, knowing what the consumers wants and needs - thus fully satisfying them with the services and products of the restaurant, is crucial. The right marketing strategies must also be in place to ensure consumer re-patronize and recommend the restaurant to others. Failing to understand consumers has devastating effects.

To gain a competitive advantage in today's market, restaurateurs must go beyond being able to offer meals that offer good value in a favourable ambience. A precise knowledge of the service and product (the service/product dimension) and the market (the marketing dimension) are essential to any business endeavour (Grimmelikhuijsen \& Porumbescu, 2017) including restaurants. This will translate into fully satisfying the consumers with the restaurant's product offerings and marketing strategies which in turn will make them want to re-patronize the restaurant in future and recommend it to others. The focus of this study will be on the post-purchase stage of a consumer's buying decision process which entails satisfaction and behavioural intentions. Decades ago, Lewis and Pizam (1981) remarked that in the foodservice industry, a large part of the product is service, which can fluctuate widely, and where guests' full satisfaction is crucial to repeat business, a comprehensive knowledge of post-purchase behaviour is particularly important.

Yuksel and Yuksel (2008) proposed that the conceptual framework of the satisfaction model should be extended by incorporating behavioral intention to find the predictive effect on satisfaction. The consequences of satisfaction decisions are important to marketers as well as public policy makers, as it is necessary to find out how satisfaction with a product or service will influence consumers' future intentions. Furthermore, by investigating the behavioral consequences of customer satisfaction with a specific service or product, it could assist marketers to better understand the link between consumer satisfactions and estimated financial outcomes of the organization (Zeithaml, Berry \& Parasuraman, 1996). Following this, a number of studies has gone beyond satisfaction alone (Armstrong and Tan, 2000) and extended the satisfaction model to include constructs such as behavioral intentions, loyalty or retention ( $\mathrm{Wu}, 2011$; Sirdeshmukh, et al. 2002).

\section{Restaurant's Service/ Product Dimensions}

Unlike material products or pure services, hospitality experience is a mixture of products and services. Therefore, overall satisfaction with a hospitality experience is a function of satisfactions with the individual elements or attributes of all the products/services that make 
up the experience (Pizam and Ellis, 1999). In the context of restaurant services, both elements of service (intangibles) and product (tangibles) are present. The food and beverage that is served by the restaurant is the physical product that delivers the service and, in addition to the physical product, consumers buy the service element (communication) and enjoy the unique grandeur upscale environment typical of a fine dining restaurant. The communication element is delivered by the front line or service staff of the restaurant and the environment element is the physical aspects of the restaurant like the ambience and physical amenities.

In a seminal work by Theodore Levitt (1981), all purchases involve intangibility and tangibility in some respects. Rust and Oliver (1994) stated that consumers must consider all purchases as services, some of which involve a physical product, others do not. Their argument is based on the premise that all products, whether they are goods or services, deliver a service. In theory, each of these components - the intangible service component and the tangible product component - constitutes only one part of the competitive package that the service firm offers (Kandampully, 2002). But in reality, from the perspective of the consumer, the two components do not exist independently. A service firm in Kandampully's (2002) view, offers a 'package' or a 'bundle of satisfaction' that includes a mixture of services, physical items, image and experience. Neither services nor goods are marketed on their own. What is marketed is a 'bundle of satisfaction'. For a restaurant, these could include the frontof-the-house service, the food and beverage, the atmospherics of the restaurant, the restaurant brand image and the customer relationship management.

The service/product dimensions for this study consist of several elements. First is the front-of-the-house or wait staff service which hereafter will be called the "front-of-the-house (FOH) service quality" to differentiate it from the widely acclaimed and popular "service quality concept" first conceived by Parasuraman et al. (1993) in several service-based industry (but not hospitality) and later on adapted by other researchers to suit their research setting. Nevertheless, the basic five elements in Parasuraman's service quality are still applicable in this study via the operationalization of service quality with the emphasis on the human element (i.e. the staff). Second is product quality, which include the food and beverage offerings of the restaurant and third, the atmospherics (the physical aspects) of the restaurant which this researcher consider as one of the products of the restaurant on the basis of Finkelsteins's (1988) and Wood's (1995) argument that the physical aspect/atmospherics of the restaurant is among the attributes that give the restaurant its particular identity and character which directly or indirectly intervene in the formation of the customer's satisfaction and post-purchase behavioral intentions. The other group or dimension is the marketing dimension, comprising of brand image and customer relationship management of the restaurant.

\section{Marketing Dimension}

The marketing dimension of the restaurant industry is a very integral component of the restaurant industry where the ability to generate business and repeat business is a critical success factor for the business (Zeithaml et al., 1996). This is even more critical in the restaurant industry as due to low switching costs, consumers have a wide array of choices of where they can dine. If they are not satisfied with their dining experience at one restaurant, it is very easy for them to choose another (Crook, Ketchen \& Snow, 2003). 
According to Shriedeh \& Abdul Ghani (2017), Customer Relationship Management (CRM) and Branding go hand in hand where both should evolved together and link seamlessly. Brand values should feed back into improved CRM (good CRM practices require good branding). Fisher (2015) mentions that CRM has been used by many brands to introduce new products - new advertising. Consumer satisfaction - both during and after 'purchase' - can be an excellent measure of a company's brand image and how consumers' feel about a company. Companies should have a 'holistic' view that branding is much more than just company's name, logos and strap lines. The power of brand values and brand image - for many the 'holy grail' of marketing - should be fully utilized to harness buying power. Brand are not just names, they're a bundle of attributes, aspirations and expectations and a reflection of how company treat their customers. The influence they have on buyer choice and future behavioral intentions like repurchase, loyalty and word-of-mouth recommendation cannot be underestimated.

\section{Repurchase/Revisit Intention}

Smith et al. (1999) grouped behavioral intentions into two categories; economic behaviors and social behaviors. Economic behavioral intentions are customer behaviors that impact the financial aspects of the firm such as repeat purchase behavior (Anderson and Mittal, 2000), willingness to pay more and switching behavior (Zeithaml et al., 1996). A positive relationship has been reported between customer satisfaction and repeat purchasing/revisitation (Szymanski and Henard, 2001). Repurchase intentions/revisitation of satisfied customers are significantly higher than the intentions of dissatisfied customers (Halstead and Page, 1992). Increasing overall satisfaction leads to greater repurchase intentions/revisitation (Anderson and Mittal, 2000), as well as actual repurchase behavior (Anderson and Mittal, 2000). For the purpose of this present research, this researcher refers to economic behavioral intentions as the intention to return or simply "revisit intention".

Consumer satisfaction theory and research have consistently supported a positive relationship between product satisfaction and repurchase/revisit intention (Howard and Sheth 1969; LaBarbera and Mazursky 1983; Oliver 1997). Intention to repurchase has not been given as much attention by researchers as it might deserve. Hunt \& Hunt (1988) posits that intention to repurchase is a simple and close substitute for consumer satisfaction. Furthermore, intention to repurchase is the satisfaction measure most salient to managers, and for this reason it merits consideration as an objective in consumer satisfaction studies which have implications for managers.

\section{Link between Consumer Satisfaction and Behavioral Intentions}

According to Gupta, McLaughlin and Gomez (2007), determining satisfaction is not sufficient, however, because one needs also to establish the link between satisfaction and repeat purchase/revisit intention, which are important sources of restaurants' profits. Hu (2005) investigation on older diners' perceptions on eight factors of restaurant's offerings including repurchase/revisit intention and word-of-mouth recommendation found that there is a positive relationship between customer satisfaction toward repurchase/revisit intention and word-of-mouth recommendation. Sulek and Hensley (2004) found that food quality is the critical attribute influencing repeat-purchase/revisit intentions in full-service restaurants while waiting time is the most important attribute in quick-service restaurants. 


\section{Methodology}

This study employed a causal research design, a type of conclusive research in which the main objective is to obtain evidence regarding cause-and-effect relationships and make inferences concerning the causal relations among the variables (Malhotra, Hall, Shaw \& Oppenheim, 2002). The data collection method was cross-sectional, as it is most widely adopted in marketing studies, where the data was collected just once. The effects being investigated can be measured from the response of the consumers or patrons of fine dining restaurant, thus it is best and more reliable if the information or data required for this study is directly garnered from the consumers' of fine dining restaurants themselves.

The self-administered survey method was used based on the premise that selfadministered questionnaires are often used in shopping centres or other central locations (like restaurants) where there is direct access to captive audience Aeker et.al (2005). A selfadministered survey is one of the data collection techniques in which the respondent reads the survey questions and records his/her own responses without the presence of a trained interviewer (Hair et. al, 2006). In addition, if respondents are selected objectively, results can be generalized to the population of interest and so provide a good basis for decision-making. Finally, survey methods are versatile; surveys can be employed in virtually any context or setting. Even though the main weakness of the survey research typically involves high nonresponse rate due to unambiguous questions or the respondents do not understand the questions, the study has taken every step possible at the pre and pilot stages to minimize the disadvantage.

Thirty of the finest fine dining restaurants in Malaysia consisting of independent free-standing restaurants as well as hotel restaurants participated in the Malaysian International Gourmet Festival (MIGF) 2017. Thus the listing of participating restaurants in the MIGF was used as the sampling frame for this study. All the pertinent details of the MIGF were published in Vision $\mathrm{KL}$, a monthly magazine that publishes all the activities happening around Kuala Lumpur. The profile of each participating restaurants including the contact number for the person in charge of the event for each hotel were also available. At the end of the process, only eight restaurants out of the many agreed to participate in the study with some conditions attached. First, they want to remain anonymous; second they want an assurance of the confidentiality of the responses and third, they will do the distribution of the questionnaire to their customers themselves.

Both probability and non-probability sampling technique were adopted in this study in order to reduce possible biases. The probability sample technique of systematic sampling was suggested to the restaurant managers in which every fourth customer who walked into the restaurant should be selected to answer the questionnaire. The managers responded that at times this is not quite possible due to the request of the customers not to be disturbed at any time they are there in the restaurant. That being the case, the non-probability technique of convenience sampling is applied when circumstances dictated it to be used. Since, the festival focused more in the Kuala Lumpur, only restaurants in Kuala Lumpur were willing to participate in the survey, the sampling scope was reduced from the intended national level (the whole country) to regional level (those in Kuala Lumpur). 
This study decided to use the drop-off and collect technique to administer questionnaire distribution. The drop-off and pick-up technique (DOPU) is also known as the personal delivery and collection technique or simply the drop off survey (Hair et al. 2003; Webster 1997) and the delivery and collection questionnaire approach (Saunders et al. 2003). In this approach, the researcher or his/her representative generally goes to where the respondent can be reached to deliver the research instrument and returns at a specified date to collect it.

The 'drop-off and pick-up' survey is a less familiar type of survey administration method compared to telephone, personal and mail surveys. It is however quite similar to the postal survey where the only difference is that the researcher or a member of field staff will deliver and call to collect the questionnaire upon completion by the respondents (Hair et al. 2003; Moutinho and Evans 1992). Despite the unfamiliarity, and in spite of the similarity, it has some unique and distinct features that blend the advantages of both the mail survey and personal interview and shares a key characteristic with the postal survey, which is the absence of an interviewer, hence eliminating response-errors due to interviewer bias (Lovelock et. al. 1976; Moutinho and Evans 1992). Past research has revealed that (as in faceto-face technique) respondents are more likely to fulfil the socially desirable responses (Keillor, Owens \& Pettijohn, 2001; Bowling, 2015).

Riley \& Kiger (2002) suggest that drop off questionnaire delivery is suitable for extensive questionnaires. In addition, Jackson-Smith et al (2016) demonstrate that mail and drop off methods have been empirically proven to be most effective in minimising non-sampling errors (e.g. non-response errors and response errors) compared to personal and telephone surveys. The nature of mail and drop off methods which do not demand immediate attention and response might contribute to this favourable outcome. The annual Malaysian International Gourmet Festival also took place on the entire month of October 2017 where participating fine dining restaurants show-cased and paraded their best cuisine to the Malaysian public at good deals.

For this study, this researcher developed the research instrument by utilizing the reviewed literature which discussed the existing theories on the measurement scale of the constructs and held discussions with the panel of supervisors as well as a statistics professor. The measurement items were also drawn from the literature that was quite frequently adopted by previous similar studies. Building on marketing literature, a survey instrument consisting of three-parts was finally developed. The instrument was designed to measure the postpurchase behaviour of restaurant consumption via a 45 items statement represented by 5 factors.

\section{Result and Analysis}

Structural Equation Modelling (SEM) was employed to analyze the causal relationships among the five constructs (representing restaurant service/product dimension and marketing dimension), satisfaction and behavioural intentions. A parsimonious model of satisfaction and behavioural intention for fine dining restaurant will also be generated by the SEM analysis. In this study, the sampling frame is the listing of all fine dining restaurants that participated in The Malaysian International Gourmet Festival (MIGF). This event was featured as an 
important event, i.e. a month-long event in the month of October on the calendar of events of Tourism Malaysia.

Initially, data was analyzed using a Confirmatory Factor Analysis (CFA) approach. CFA is a statistical technique that enables a researcher to assess relationships among both manifest (i.e., observed) and latent variables for the purpose of testing a theoretical model or confirming the factor structure of a research instrument (Kline, 2016). The goodness of fit of all CFA and structural model followed the accepted standards levels of normed $\chi^{2}$ of $>3$, RMSEA (<.08) and GFI (> .95). Assessment of normality was carried out to determine data distribution. Joint multivariate kurtosis value and associated critical ratio showed that there is a moderate degree of normality; therefore, transformation was needed in order to rectify the situation (data influencing the results). Following transformation, a Bollen-Stine bootstrap procedure (2000 iterations) was employed (Kline 2016). The result from this analysis for measurement model indicates that the $p$ value was $<.05$ (.107) indicating that the measurement model fit was not inflated.

A total of 1200 questionnaires were handed out to the eight participating restaurants. 494 surveys were returned but 75 were discarded due to invalid response i.e. monotonous and many incomplete answers. In the end, there were 419 useable surveys which yielded a response rate of $35 \%$.

The initial analysis on convergent validity and inter-item discriminant validity assessment as well as the inter-item correlation matrix of the items were inspected for each construct. Discriminant validity can be established if the correlations is not too high $(<0.85)$. The convergent validity can be said to be fulfilled if the inter-item correlation is more than 0.35 . For the reliability test, the data recorded acceptable result. The next step in the data analysis was to establish the construct validity (convergent and discriminant validity) of the five dimensions. The average variance extracted (AVE) was calculated for each of the five constructs representing the service/product, marketing dimensions, satisfaction and behavioural intentions. Table 1 provides evidence for adequate composite reliability and construct validity.

Table 1.0: Composite Reliability and Validity.

\begin{tabular}{|c|c|c|c|c|}
\hline Model Fit & Construct & Loading & CR & AVE \\
\hline $\begin{array}{l}\chi^{2} / \mathrm{df} \text { of } 1.75, \\
p=.000 \text { and CFI } \\
\text { of .992 }\end{array}$ & $\begin{array}{l}\text { Service Quality } \\
\text { (8 items) } \\
\text { Variance Explained- } 72 \%\end{array}$ & $\begin{array}{l}.670 \\
.761 \\
.718 \\
.790 \\
.807 \\
.770 \\
.741 \\
.741\end{array}$ & .96 & .72 \\
\hline
\end{tabular}




\begin{tabular}{|c|c|c|c|c|}
\hline & & .789 & .93 & .73 \\
\hline & Product Quality & .838 & & \\
\hline & (8 items) & .829 & & \\
\hline & & .822 & & \\
\hline & Variance Explained- 73\% & 881 & & \\
\hline & & .887 & & \\
\hline & & .843 & & \\
\hline & & .860 & & \\
\hline & Atmosphere & .883 & .94 & .73 \\
\hline & (6 items) & .858 & & \\
\hline & & .898 & & \\
\hline & Variance Explained- 74\% & .866 & & \\
\hline & & .849 & & \\
\hline & & .886 & & \\
\hline & Brand Image & .882 & .93 & .77 \\
\hline & (6 items) & .915 & & \\
\hline & & .899 & & \\
\hline & Variance Explained- 76.3\% & .890 & & \\
\hline & & .845 & & \\
\hline & & .857 & & \\
\hline$\chi 2 / d f$ of 1.85 & Satisfaction & .879 & .95 & .79 \\
\hline $\mathrm{p}=.000$ and $\mathrm{CFI}$ & (6 items) & .911 & & \\
\hline of .911 & & .885 & & \\
\hline & Variance Explained- 79.4\% & .879 & & \\
\hline & & .879 & & \\
\hline & & .912 & & \\
\hline$\chi^{2} / \mathrm{df}$ of 1.74 & Revisit Intention & .966 & .96 & .93 \\
\hline $\mathrm{p}=.041$ and $\mathrm{CFI}$ & (2 items) & .966 & & \\
\hline & Variance Explained- 93.2\% & & & \\
\hline
\end{tabular}

\section{- $\quad$ Composite Reliability $(C R)>.7$; strong reliability and convergent validity}

- $\quad$ Average Variance Extracted (AVE) > .5 shows strong discriminant validity

With these results, we proceeded to test the structural model to assess its causal and the significance of its paths. Structural model indicates that the chi-square value of 177.67 is significant at the $p<.05$ level $(p=.000)$. In this case, the $\chi^{2} / \mathrm{df}$ of 1.83 and CFI of .987 indicates a good fit between the hypothetical model and the sample data. The RMSEA for the measurement model was 0.048 . Other fit indices also point to an acceptable model fit between the model and the data $(\mathrm{GFI}=0.958, \mathrm{AGFI}=0.925, \mathrm{CFI}=0.987)$ as shown in Table 2 . 
INTERNATIONAL JOURNAL OF ACADEMIC RESEARCH IN BUSINESS AND SOCIAL SCIENCES

Vol. 11, No. 13, Beyond 2021 and COVID-19 - New Perspective in the Hospitality \& Tourism Industry. 2021, E-ISSN: 2222-6990 @ 2021 HRMARS

Table 2.0: Measurement Model Fit Indices

\begin{tabular}{lccccccc}
\hline Model & CMIN/DF & AGFI & CFI & TLI & NFI & IFI & RMSEA \\
\hline Default & 1.83 & .925 & .987 & .960 & .929 & .964 & .048 \\
\hline Saturated & & 1.000 & 1.000 & & 1.000 & 1.000 & \\
\hline Independence & 24.647 & .064 & .000 & .000 & .000 & .000 & .241 \\
\hline
\end{tabular}

From various running and testing the measurement model, a final parsimonious model resulted. The Final Model Standardized Path Coefficients or Final Model Pathways is depicted here as Figure 2.0 with Table 3.0 showing the Summary of Path Coefficients of the Final Parsimonious Model.

Table 3.0: Summary of Path Coefficients of the Final Parsimonious Model

\begin{tabular}{cccccccc}
\hline \multicolumn{2}{c}{ Causal Path } & $\begin{array}{c}\text { Unstandardized } \\
\text { Estimate }\end{array}$ & S.E. & C.R. & P & $\begin{array}{c}\text { Standardized } \\
\text { Estimate }\end{array}$ \\
\hline Brand & $<---$ & Product & .907 & .053 & 17.100 & $* * *$ & .883 \\
\hline CM & $<---$ & Brand & 1.162 & .057 & 20.561 & $* * *$ & .938 \\
\hline Satis & $<---$ & Product & .368 & .112 & 3.274 & .001 & .295 \\
\hline Satis & $<---$ & Atmos & .131 & .102 & 1.283 & .200 & .116 \\
\hline Satis & $<---$ & CM & .350 & .074 & 4.726 & $* * *$ & .357 \\
\hline Revisit & $<---$ & Satis & .746 & .045 & 16.451 & $* * *$ & .675 \\
\hline Revisit & $<---$ & Product & .251 & .059 & 4.289 & $* * *$ & .183 \\
\hline
\end{tabular}




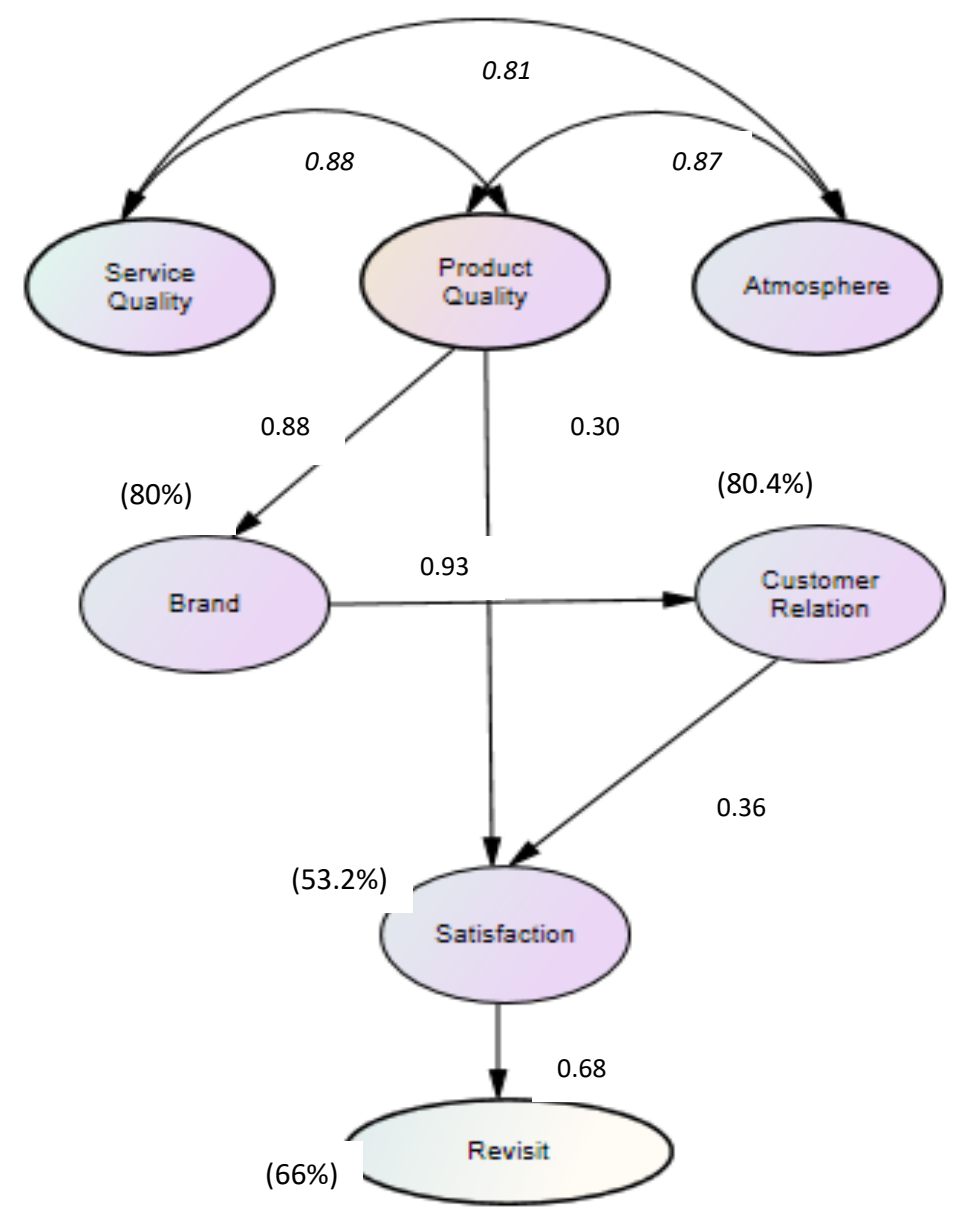

Figure 2: Final Model Pathways

Table 4.0: Total, direct and indirect effects

\begin{tabular}{llccccccc}
\hline \multirow{2}{*}{$\begin{array}{l}\text { Dependent } \\
\text { variables }\end{array}$} & \multicolumn{6}{l}{ Independent variables } \\
\cline { 2 - 9 } Brand Image & Effect & AQ & PQ & SQ & BI & CM & st6 & rv1 \\
& Total & - & .883 & - & - & - & - & - \\
& Direct & .883 & - & - & - & - & - & - \\
& Indirect & - & - & - & - & - & - & - \\
\hline Customer & Total & - & .828 & - & .938 & - & - & - \\
Management & Direct & - & - & - & .938 & - & - & - \\
(CM) & Indirect & - & .828 & - & - & - & - & - \\
\hline \multirow{4}{*}{ Satisfaction } & Total & .116 & .591 & - & .335 & .357 & - & - \\
& Direct & .116 & .295 & - & - & .357 & - & - \\
& Indirect & - & .296 & - & .335 & - & - & - \\
\hline \multirow{2}{*}{ Revisit } & Total & .078 & .582 & - & .226 & .241 & .675 & - \\
& Direct & - & .183 & - & - & - & .675 & - \\
& Indirect & .078 & .399 & - & .226 & .241 & - & - \\
\hline
\end{tabular}




\section{Interpretation of the Final Model Pathways}

The three constructs $\mathrm{SQ}, \mathrm{PQ}$ and $\mathrm{AQ}$ are strongly correlated to each other as shown by the coefficients in italic $(0.88,0.81$, and 0.87$)$. Correlation is a measure of the degree to which two variables are associated and the strength of associations between two variables can be determined through the correlation analysis. It is important to note that correlation analysis is not used for the purpose of hypothesis testing; however, the correlation matrix illustrates the strength of association among construct dimensions.

The hypothesized premise of the study at the onset was the 5 constructs of fine dining restaurants namely service quality (SQ), product quality (PQ), atmospherics quality ( $A Q)$, brand image (BI) and customer relationship management (CM) have a direct effect on predicting overall satisfaction (Satis) and revisit intentions (revisit). Three of these constructs $(\mathrm{SQ}, \mathrm{PQ}, \mathrm{AQ}$ ) represents the service/product dimension of the restaurant whilst the other two other constructs represent the marketing dimension. In addition, overall satisfaction was hypothesized to have a direct effect on revisit intentions (revisit). The findings of this study revealed a mixed support for the hypotheses where some were supported and some were not as is envisaged in Table 5. The interpretation of the final model pathways is as shown by Figure 1.

The service quality (SQ) has no direct effect on satisfaction (satis) on its own. This can be seen from Figure 2 where there is no single headed arrow leaving SQ and entering st6. Also from Table 4 which shows the total, direct and indirect effects, the direct effect of SQ to satisfaction is zero. But together with product quality (PQ) and atmospheric quality ( $A Q$ ) (as indicated by a high correlation value of 0.88 and 0.81 respectively), SQ has an effect on satisfaction. This justifies the earlier contention that the front-of-the-house service quality (SQ) has no direct effect on satisfaction on its own.

Product quality has a direct effect on satisfaction (0.3). In social science a coefficient value of greater than 0.14 or $14 \%$ is an indication of strong relationship (Cohen, 1988), this effect is quite substantial. Product quality also has an indirect effect on satisfaction via $\mathrm{PQ} \rightarrow \mathrm{BI}(0.883)$, $\mathrm{BI} \rightarrow \mathrm{CM}$ (0.938), $\mathrm{CM} \rightarrow$ satis (0.357), making the total indirect effect $0.883 \times 0.938 \times 0.357=$ 0.296 as shown in Table 4 . As any value greater than 0.085 shows a meaningful indirect effect according to Hair et al (1988), the indirect relationship between product quality and satisfaction is also substantial. Brand image has no direct effect on satisfaction but through the mediation of customer relationship management, it has an indirect effect of 0.335 $\left[\mathrm{BI} \rightarrow \mathrm{CM}(.938) \times \mathrm{CM} \rightarrow\right.$ satisfaction $\left.(.357)=0.3348^{\sim 0.335}\right]$. This relationship can also be seen in Table 4.

With respect to the relationship with revisit intention, only one of the five constructs i.e. product quality has both direct and indirect effect on revisit intention. Product quality has a direct effect on revisit intention (0.18). Product quality also has an indirect effect on revisit intention via $\mathrm{PQ} \rightarrow \mathrm{BI}(0.883), \mathrm{BI} \rightarrow \mathrm{CM}$ (0.938), $\mathrm{CM} \rightarrow$ satis $(0.357)$, satis $\rightarrow$ revisit(0.675) and $\mathrm{PQ} \rightarrow$ satis (0.295), satis $\rightarrow$ revisit $(0.675)$, making the total indirect effect $[0.883 \times 0.938 \times$ $\left.0.357+0.295 \times 0.675=0.3987^{\sim} 0.399\right]$. The other four constructs namely service quality, atmospherics quality, brand image and customer relationship management have no direct effect on revisit intention. 
Atmospherics quality has an indirect effect to revisit intention (0.078) through the mediation of satisfaction [AQ $\rightarrow$ satis (0.116), satis $\rightarrow$ revisit (0.675), $0.116 \times 0.675=0.078$ (as in Table 4). However as $0.078<0.085$ (Hair et al, 1988), this relationship is not very meaningful. Brand image has an indirect effect to revisit intention (0.226) through the mediation of customer relationship management and satisfaction $[\mathrm{BI} \rightarrow \mathrm{CM}(0.94)], \mathrm{CM} \rightarrow$ satis (0.36), satis $\rightarrow$ revisit $(0.68)==>0.94 \times 0.36 \times 0.68=0.226$, as shown in Table 4]. Customer relationship management has an indirect effect on revisit intention $[\mathrm{CM} \rightarrow$ satis $(0.36)$, satis $\rightarrow$ revisit $(0.68)==>0.36 \times 0.68$ $=0.241$ as shown in Table 4]. Satisfaction has a direct effect on revisit intention (0.68) as seen in Table 4.

The figures in parentheses are the squared multiple correlation estimates, which represent the percentage explained variation. From Figure 1, it is seen that $80 \%$ of the variation in brand image is explained by product quality. Similarly, $80.4 \%$ of the variations in customer relationship management is explained by brand image and product quality. Likewise, $53 \%$ of the variation in overall satisfaction is explained by product quality, brand image and customer relationship management.

Table 5.0: Hypotheses Results

\begin{tabular}{lllll}
\hline Causal Path & $\begin{array}{l}\text { Hypoth } \\
\text { esis }\end{array}$ & $\begin{array}{l}\text { Standardized } \\
\text { Coefficient }\end{array}$ & $\begin{array}{l}\text { Critical } \\
\text { Ratio }\end{array}$ & $\begin{array}{l}\text { Assessment } \\
(P<0.05)\end{array}$ \\
\hline $\mathrm{SQ} \rightarrow$ Satisfaction & $\mathrm{H}_{1 \mathrm{a}}$ & & & Not Significant \\
\hline $\mathrm{PQ} \rightarrow$ Satisfaction & $\mathrm{H}_{1 \mathrm{~b}}$ & .295 & 3.274 & Significant \\
\hline $\mathrm{AQ} \rightarrow$ Satisfaction & $\mathrm{H}_{1 \mathrm{c}}$ & .116 & 1.283 & Not Significant \\
\hline $\mathrm{BI} \rightarrow$ Satisfaction & $\mathrm{H}_{2 \mathrm{a}}$ & & & Not Significant \\
\hline $\mathrm{CM} \rightarrow$ Satisfaction & $\mathrm{H}_{2 \mathrm{~b}}$ & .357 & 4.726 & Significant \\
\hline $\mathrm{SQ} \rightarrow$ Revisit & $\mathrm{H}_{3 \mathrm{a}}$ & & & Not Significant \\
\hline $\mathrm{PQ} \rightarrow$ Revisit & $\mathrm{H}_{3 \mathrm{~b}}$ & .183 & 4.289 & Significant \\
\hline $\mathrm{AQ} \rightarrow$ Revisit & $\mathrm{H}_{3 \mathrm{c}}$ & & & Not Significant \\
\hline $\mathrm{BI} \rightarrow$ Revisit & $\mathrm{H}_{4 \mathrm{a}}$ & & & Not Significant \\
\hline $\mathrm{CM} \rightarrow$ Revisit & $\mathrm{H}_{4 \mathrm{~b}}$ & & & Not Significant \\
\hline Satisfaction $\rightarrow$ Revisit & $\mathrm{H}_{5}$ & .675 & 16.451 & Significant \\
\hline
\end{tabular}

\section{Conclusion}

A parsimonious model of restaurant satisfaction and behavioural (revisit) intention was successfully developed and the proposed framework was substantially validated. From the data set of this study, it was found that out of the eleven hypotheses tested (main and subhypotheses), four were supported and seven were not. Product quality and customer relationship management were found to be significant predictors of overall satisfaction among consumers of fine dining restaurant whilst front-of the-house service quality, atmospherics quality and brand image were not. Product quality has a significant relationship with revisit intention whilst front-of-the-house service quality, atmospherics quality and brand image did not. And lastly, overall satisfaction was also found to be a significant predictor of revisit intention. 
The results of this study reflected both theoretical and practical implications that have significant relevance and great importance to both academicians and practitioners. For the academia, the empirical determination of the direction and significance of the relationships between the variables studied adds new knowledge to the literature and more studies could be built on upon it. For the practitioners in the industry, the findings can be put to good use in improving their business in today's very complex and competitive business environment.

As with other research study endeavours, this study has its fair share of limitations as well. Firstly, getting the cooperation from the industry is a major issue where getting them to cooperate in this study is quite difficult. Even if they do agree to participate, there are some limitations imposed by them which make it difficult for researchers to comply exactly with the ideals in conducting research. An example of this is the researchers weren't allowed direct access to the restaurant's patrons which hampered some ideal sampling techniques. Secondly, the intent to conduct the study on fine dining restaurants all over the country was also hampered due to several reasons beyond control. There is limited number of fine dining restaurants out of the Klang Valley, there are not many fine dining restaurants to sample from the sampling frame and restaurants out of the Klang Valley were not willing to participate in this research study. Thus, the findings of this study could not be generalized to the whole country.

As the Malaysian hospitality industry is very short on scientific and empirical research, much additional studies in this area studies should be conducted to further investigate issues related to the industry. Researches of this nature will undoubtedly enrich the local hospitality body of knowledge and be of paramount importance to the industry at large. Replication of this study in other segments of restaurants in Malaysia such as the quick service restaurants, the casual dining segments and the ethnic restaurants is recommended to further expand industry-wide knowledge.

\section{Corresponding Author}

Salim Bin Abdul Talib.

Faculty of Hotel and Tourism Management, Universiti Teknologi MARA, Puncak Alam Campus, 42300, Selangor, Malaysia.

Email: salim@uitm.edu.my

\section{References}

Aaker, D. A., Kumar, V., Day, G. S., \& Lawley, M. (2005). Marketing research. The pacific rim edition. Queensland: John Wiley \& Sons Australia, Ltd.

Alexandris, K., Dimitriadis, N, \& Markata, D. (2002). Can perception of service quality predict behavioural intentions? An exploratory study in the hotel sector in Greece. Managing Service Quality, 12(4), 224-233.

Anderson, E. W., \& Mittal, V. (2000). Strengthening the satisfaction-profit chain. Journal of Services Research, 3(2), 107-20.

Armstrong, R.W. \& Tan, B.S. (2000). Corporate-customer satisfaction in the banking industry of Singapore. The International Journal of Bank Marketing. 18(3), 97-104. 
Andaleeb, S. S., \& Conway, C. (2006). Customer satisfaction in the restaurant industry: An examination of the transaction-specific model, Journal of Services Marketing, 20(1), 311.

Biswas, R., \& Cassel, C. (1996). Strategic HRM and the gendered division of labour in the hotel industry: A case study. Personnel Review, 25(2), 19-28.

Bowling, A. (2015). Mode of Questionnaire Administration Can Have Serious Effects on Data Quality, Journal of Public Health, 27 (3), 281-291.

Brick, J. M., \& Douglas, W. (2013). Explaining Rising Non-Response Rates in Cross-Sectional Surveys. The Annals of the American Academy of Political and Social Science, 645 (1), 36-59.

Crook, T. R., Ketchen, D. J., \& Snow, C. C. (2003). Competitive edge: A strategic management model. The Cornell Hotel and Restaurant Administration Quarterly, 44(3), 44.

Finkelstein, J. (1988). Dining Out: A Sociology of Modern Manners. Polity Press: Cambridge.

Fisher, L. (2015). How CRM is becoming the 'new advertising'. Retrieved from https://www.marketingweek.com/2015/11/09/how-crm-is-becoming-the-newadvertising?/

Fryet, D. K. (2015). Global Trends Affecting the Food Service Industry Today and Tomorrow. Retrieved from http://fryettcg.com/deepfryett/2014/11/global-trends-affecting-thefood-service-industry-today-tomorrow/

Grimmelikhuijsen, S., \& Porumbescu, G. A. (2017). Reconsidering the expectancy disconfirmation model. Three experimental replications. Public Management Review, 19 (9), 1272-1292, https://doi.org/10.1080/14719037.2017.1282000

Hair, J. F., Bush, R. P., \& Ortinau, D. J. (2006). Marketing research: Within changing information environment (3rd ed). New York, NY: McGraw-Hill Irwin.

Halstead, D., \& Page, T. J. Jr. (1992). The effects of satisfaction and complaining behavior on consumer repurchase intentions. Journal of Consumer Satisfaction, Dissatisfaction and Complaining Behavior, 5, 1-11.

Hu, S. H. (2005). A structural equation model of the senior citizens' purchasing process in foodservice: Considering the quality of food, nutrition, service and entertainment in foodservice environment. (Unpublished Doctoral Dissertation). The Oklahoma State University.

Hunt, N. K., Hunt, N. D., \& Hunt, T. C. (1988). Consumer grudgeholding. Journal of Consumer Satisfaction, Dissatisfaction and Complaining Behavior, 1, 116-118.

Santouridis, I., \& Veraki, A. (2017). Customer relationship management and customer satisfaction: the mediating role of relationship quality. Total Quality Management \& Business $\quad 28$ (9-10), 1122-1133, https://doi.org/10.1080/14783363.2017.1303889

Jackson-Smith, D., Flint, C. G., Dolan, M.; Trentelman, C. K., Holyoake, G., \& Thomas, B. (2016). Effectiveness of the Drop-off/Pick-up Survey Methodology in Different Neighbourhood Types, Journal of Rural Social Sciences, 31(3), 35-67.

Kandampully, J. (2002). Services management: the new paradigm in hospitality. New South Wales: Hospitality Press/Pearson Education Australia.

Keillor, B., Owens, D., \& Pettijohn, C. (2001). A cross-cultural/cross-national study of influencing factors and socially desirable response biases. International Journal of Market Research, 43(1), 63-84. 
Kline, R. B. (2016). Principles and Practices of Structural Equation Modeling (4 ${ }^{\text {th }}$ ed), London: Guilford Press.

Kivela, J., Inbakaran, R., \& Reece, J. (1999a). Consumer research in the restaurant environment. Part 1: A conceptual model of dining satisfaction and return patronage. International Journal of Contemporary Hospitality Management, 11(5), 205-222.

Lewis, R. C., \& Pizam, A. (1981). Guest surveys: A missed opportunity. The Cornell Hotel and Restaurant Administration Quarterly, November, 37-44.

Loureior, S. M. C., \& Gonzalez, F. J. M. (2008). "The Importance of Quality, Satisfaction, Trust, and Image in Relation to Rural Tourist Loyalty". Journal of Travel \& Tourism Marketing, 25(2), 117-36.

Malhotra, N., Hall, J., Shaw, M. \& Oppenheim, P. (2002). Marketing research: An applied orientation, (2nd Ed.). New South Wales: Pearson Education Australia.

Oliver, R. L. (1997). Satisfaction: A Behavioral Perspective on the Consumer. New York: McGraw-Hill.

Parasuraman, A., Berry, L. L., \& Zeithaml, V. (1993). More on improving service quality measurement. Journal of Retailing, 69(1), 140-147.

Pizam, A., \& Ellis, T. (1999). Customer satisfaction and its measurement in hospitality enterprises. International Journal of Contemporary Hospitality Management, 11(7), 326-339.

Riley, P.J. \& Kiger, G. (2002) Increasing survey response: The drop-off/pick-up technique, The Rural Sociologist, 22(1), 6-9.

Rosier, E. R. (2011). Marketing Strategy in Turbulent Environment. Journal of Strategic Marketing, 19(5), 413-419.

Rust, R. T., \& Oliver, R. L. (1994). Service quality: New directions in theory and practice. Thousand Oaks, California: Sage Publications.

Scott-Delany, F. (2017). Restaurant growth is up, but turbulent times lie ahead, retrieved from https://www.bighospitality.co.uk/Article/2017/09/22/

Shriedeh, F., \& Abd. Ghani, N. H. (2017). Impact of Customer Relationship Management on Brand Equity: Medical Tourist Perspective. Research Journal of Business Management, 11, 28-38.

Smith, A. K., Bolton, R. N., \& Wagner, J. (1999). A model of customer satisfaction with service encounters involving failure and recovery. Journal of Marketing Research, 36(3), 35672.

Tourism Malaysia. (2018). Malaysia Tourism Statistics in Brief. Retrieved from https://www.tourism.gov.my/statistics

Theordore, L. (1981). Marketing Intangible Products and Product Intangibles. Harvard Business Review, retrieved from https://hbr.org/1981/05/marketing-intangibleproducts-and-product-intangibles

Wood, R. C. (1995). The Sociology of the Meal. Edinburgh: Edinburgh University Press.

Yuksel, A., \& Yuksel, F. (2008). Consumer Satisfaction Theories: A Critical Review, in Atila Yuksel (ed) Tourist satisfaction and complaining behaviour: Measurement and Management Issues in the Tourism and Hospitality Industry, New York: Nova Science.

Zeithaml, V. A., Berry, L. L., \& Parasuraman, A. (1996). The behavioural consequences of service quality. Journal of Marketing, 60, 31-46. 